\title{
An application of blended amendments in monsoon rice field
}

\author{
Madhumita Ghosh ${ }^{*}$ and Ashalata Devi
}

\begin{abstract}
Introduction: Rice is the main food crop of the world, and the cultivation of rice crop during the monsoon season is hard due to the rain-induced waterlogging. Apart from this, farmers in north-eastern regions of India often implement improper crop management leading to poor yields. Thus, the development of suitable management practices under improved varieties of rice become essential for increasing rice productivity, improving soil quality status and reducing methane emission.

Methods: The aim of the study was to investigate the variation in soil properties, crop growth and methane emission under the application of an inorganic fertiliser as well as its mixtures with both inorganic and plant materials. In such an attempt, a field-based experiment was conducted with the rice variety Chandrama during 2015 in slightly acidic soil having sandy loam texture. Five amendments, i.e. NPK and NPK, blended separately with magnesium sulphate, fresh neem (Azadirechta indica) leaves, used tea (Camellia sinensis var. assamica) leaves, and fresh karanj (Pongamia glabra) leaves were used for the study with four replications each.
\end{abstract}

Results: Application of NPK separately with the leaves of neem, tea and karanj separately at the onset of monsoon season markedly affected the soil porosity and the water-holding capacity of the soil. However, in comparison with sole NPK fertilisation, a significance increase in soil organic matter accumulation $(2.48 \pm 0.10 \%)$ was seen only for karanjblended NPK while magnesium sulphate-blended NPK showed the lowest methane emission $\left(0.30 \pm 0.01 \mathrm{mg} / \mathrm{m}^{2} / \mathrm{h}\right)$. The rice plants grown on karanj-blended NPK soil showed the highest yield $\left(0.560 \pm 0.01 \mathrm{~kg} / \mathrm{m}^{2}\right)$ among the five amendments.

Conclusions: It was found that only the karanj leaves blended NPK could significantly improve the soil organic matter and increase rice yield without intensifying methane emission, while magnesium sulphate blended with NPK could significantly reduce methane emission in the flooded rice paddy soil at $0.5 \mathrm{t} / \mathrm{ha}$ application level but exhibit lower rice yield.

Keywords: Inorganic fertiliser, Leaves of plants, Soil properties, Rice yield, Methane emission

\section{Introduction}

Rice (Oryza sativa L.) is a basic food for more than half of the people in the world (FAO 2011; Mackill et al. 2012) and is cultivated in 155 million hectares of land world-wide almost throughout the year (FAOSTAT 2006). Growing rice during the monsoon season in South and Southeastern Asia is difficult because of waterlogging of low-lying fields leading to iron toxicity, zinc deficiency and fall in leaf chlorophyll content in an acidic soil condition. All of these results in 15 to $30 \%$

* Correspondence: mghosh@tezu.ernet.in

Department of Environmental Science, Tezpur University, P.O-784028 Napaam, India

(c) The Author(s). 2017 Open Access This article is distributed under the terms of the Creative Commons Attribution 4.0 International License (http://creativecommons.org/licenses/by/4.0/), which permits unrestricted use, distribution, and reproduction in any medium, provided you give appropriate credit to the original author(s) and the source, provide a link to the Creative Commons license, and indicate if changes were made. rice yield loss and even complete crop failure in wetland rice (Audebert and Sahrawat 2000; Becker and Asch 2005). Waterlogging of rice field not only reduces rice yield (Kato et al. 2014; Vergara et al. 2014) but also is a source of methane emission affecting global warming (Aulakh et al. 2001). About 11\% of anthropogenic methane emissions come from rice paddies (IPCC 2013), and among the major cereals, rice has the highest global warming potential (GWP) due to high methane emissions (Linquist et al. 2012). Therefore, a sustainable rice cropping requires yield increment while reducing methane emissions (Chen et al. 2014; Linquist et al. 2012; van der Gon et al. 2002) as the global demand for rice is

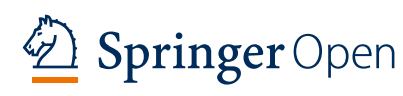


likely to increase from 644 million tons in 2007 to 827 million tons in 2050 (Alexandratos and Bruinsma 2012).

Maintaining food security in the face of population growth and climate change is one of the great challenges facing mankind today (Alexandratos and Bruinsma 2012). The mitigation practices that are applied to curb methane emission from rice paddies include mid-season drainage, intermittent irrigation, no-till and the use of alternative fertilisers (Hussain et al. 2015; Linquist et al. 2015; Zhao et al. 2016). However, these practices can result in yield losses (Pittelkow et al. 2015) and are labor-intensive, and their applicability varies among rice cropping systems and countries (Bodelier 2015). In contrast, use of high-yielding varieties may be a win-win strategy, as these simultaneously decrease methane emissions and increase grain yield. Although seeds of high-yielding cultivars will be more expensive, farmers are benefited with an increase in grain yield that exceeds extra cost and ecosystem benefits through the reduction in greenhouse gases.

Rice productivity, soil health and mitigation of methane in paddy soil also depend on field management practices during rice cultivation. Suitable soil amendment recommendations specific for rainfed lowland rice are currently not available (Sarangi et al. 2016). Thus, providing recommendations that require relatively less investments but have higher returns are likely to be adopted by farmers (Linquist and Sengxua 2001). Addition of leaves of neem, used tea leaves and karanj are traditionally known to increase yield and improve soil health. Besides, providing an alternate source of substrate for the use of soil microorganisms, leaves of neem and karanj activate methane-oxidising microorganisms there by reducing methane emission from paddy fields (Datta and Adhya 2014). These leaves are commonly available and are selected with a perspective of improving soil health while reducing methane emission. In this direction, a field experiment was conducted by growing a high-yielding variety Chandrama with amendments consisting of NPK, NPK mixed with magnesium sulphate $\left(\mathrm{MgSO}_{4}\right)$ and NPK mixed with each of the plant-based materials namely fresh neem (Azadirechta indca) leaves, used tea (Camellia sinensis var. assamica) leaves and fresh karanj (Pongamia glabra) leaves in sali (monsoon) rice ecosystem and investigating their effects on soil properties, crop growth and methane emission.

\section{Methods}

\section{Experimental site}

A field experiment was conducted inside the Tezpur University campus $\left(26^{\circ}-41^{\circ} \mathrm{N}\right.$ to $92^{\circ}-50^{\circ} \mathrm{E}$ and $48 \mathrm{~m}$ above sea level) in Assam, northeast India, during the monsoon season (July-November) in 2015. The experimental site belongs to North Bank Plain agroclimatic zone of Assam. The region experiences a subtropical humid type of climate with moderately hot wet summers and dry winters. The soil of the experimental field has a sandy loam texture and rich in organic matter. Soil samples collected at a depth of $0-15 \mathrm{~cm}$ were taken randomly from different sites within the field before starting the experiment and were dried, sieved and analysed for the physico-chemical properties (Table 1).

\section{Description of the rice variety \\ Chandrama (CR-386-2-10) (IET 9354, 10419) is a semi dwarf $(105-110 \mathrm{~cm})$ released in 2007 with parentage ARC6650 × CR94-721-3. It grows in shallow lowlands and irrigated areas of Assam for both sali (monsoon) and boro (summer) rice seasons. It matures in 135-140 days during sali season with a yield of $5 \mathrm{t} / \mathrm{ha}$.}

Description of blended amendments and experimental design The blended amendments consisted of T1:NPK, T2:NPK $+\mathrm{MgSO}_{4}(0.5 \mathrm{t} / \mathrm{ha}), \mathrm{T} 3: \mathrm{NPK}+$ fresh neem leaves $(1 \mathrm{t} / \mathrm{ha})$, T4:NPK + used tea leaves (1 t/ha) and T5:NPK + fresh karanj leaves (1 t/ha). The recommended dose of inorganic fertiliser, NPK, was applied at a rate of 60:20:40 kg/ha. The nitrogen was applied in the form of urea, phosphate in the form of single super phosphate and potassium in the form of muriate of potash. The $\mathrm{MgSO}_{4}$ and leaves of selected plant materials were blended in soil with NPK in their respective plots according to field layout and were applied 2 days before transplantation as basal fertiliser. In case of urea, out of the $60 \mathrm{~kg} / \mathrm{ha}, 30 \mathrm{~kg} / \mathrm{ha}$ was applied as basal fertiliser at the time of transplantation and the rest of the $30 \mathrm{~kg} / \mathrm{ha}$ was divided into two equal parts of $15 \mathrm{~kg} / \mathrm{ha}$ each. One part of the urea was applied at the time of tillering and other part at the time of panicle initiation.

Table 1 Physico-chemical properties of soil recorded prior to experimental work

\begin{tabular}{ll}
\hline Property & Values \\
\hline Moisture (\%) & 32.14 \\
Soil temperature $\left({ }^{\circ} \mathrm{C}\right)$ & 30.01 \\
Soil electrical conductance $(\mu \mathrm{s} / \mathrm{cm})$ & 55.00 \\
Redox potential $(\mathrm{mV})$ & 132.0 \\
Porosity (\%) & 28.00 \\
Water-holding capacity (\%) & 40.00 \\
Total nitrogen $(\mathrm{mg} / \mathrm{g})$ & 0.58 \\
Total carbon $(\mathrm{mg} / \mathrm{g})$ & 2.38 \\
Soil organic matter $(\%)$ & 3.19 \\
Copper $(\mathrm{ppm})$ & 7.72 \\
Manganese $(\mathrm{ppm})$ & 16.39 \\
\hline
\end{tabular}


The study area was mapped out into 20 experimental plots in $5 \times 4$ matrix. Each plot measuring $4 \mathrm{~m}^{2}$ $(2 \mathrm{~m} \times 2 \mathrm{~m})$ having interplot and interreplicate distances of $0.5 \mathrm{~m}$. Each of the plots was applied with any of the five treatments such that one treatment was used only once in a row and also once in a column. A high-yielding rice variety, Chandrama, was used for the study. The seeds of this variety were sown at a rate of $45 \mathrm{~kg} / \mathrm{ha}$ in a raised nursery bed. The field was ploughed thoroughly and was flooded for 2 to 3 days before transplantation. Three seedlings of 32 days old were transplanted in each hill (pit) of a plot with a row-to-row spacing of $20 \mathrm{~cm}$ and plant-toplant spacing of $15 \mathrm{~cm}$. The crop was rainfed, and hence, no irrigation was applied after establishment of the crop. Other management practices, such as weeding, and plant protection measures were uniformly maintained over the experimental plots as recommended by the Assam Agriculture University, Jorhat India.

\section{Soil sampling and analysis}

The soil samples were collected at three stages of crop growth namely tillering (branching), panicle initiation and flowering, and also at harvest. The samples were collected from five different places within an individual plot by a soil core sampler (5-cm inner diameter and 20-cm height) from a depth of $0-15 \mathrm{~cm}$. The five soil samples so obtained were mixed together to prepare a composite sample for that plot and carried to laboratory in a sealed polythene bag. Immediately after sampling, a part of soil sample was used to obtain soil moisture, porosity and water-holding capacity. With the rest part of the sample, easily identified organic matter (roots, stems, leaves) was removed and air-dried in open for 7 days and, later, the soil was ground with a wooden hammer and sieved through a 2-mm diameter mesh. Such soil samples were used to find soil $\mathrm{pH}, \mathrm{EC}$, redox potential, soil organic matter and soil nutrients like copper and manganese.

The soil pH, EC and redox (1:5 soil: water ratio) were measured using a Systronics Griph model D, the soil organic carbon by Walkly and Black (1934). The SOM concentration in soil sample was calculated using the formula $(\mathrm{SOM}=\mathrm{SOC} \times 1.724)$ given in Ruehlmann and Korschens (2009). The total nitrogen and total carbon were analysed by CHN analyser (model: 2400 series2, $U S A)$. The available nitrogen, available phosphorus and available potassium were analysed by methods described by Page et al. (1982). The micronutrients were extracted using DTPA and analysed by mass spectrophotometer (Perkin Elmer Optima 2100DV).

\section{Plant sampling and analysis}

The plant height, tiller number and leaf number were obtained from the plants of three hills selected from three random plots per treatment, excluding boarder rows and columns of the plots. Destructive sampling was done for the estimation root length. For this, three plants per treatment were removed from the experimental site. After removing the struck soil by washing under gentle flow of tap water, root length of plants were measured with a measuring scale. Leaf area was measured by a portable laser leaf area meter (CID, Model CI-203, USA).

\section{Yield parameters}

For estimating yield, a random area of $1 \mathrm{~m} \times 1 \mathrm{~m}$ size was selected from each plot excluding boarder rows and columns of the plot. Such an area includes five rows and six columns of cultivation, i.e. a total of 30 hills of plantation. The plants just above the ground level were harvested from all the thirty hills of each plot. The grains were separated from straw, dried and weighed to get yield. For measuring the length of panicles at harvest, five panicles each from three replications per treatment was taken arbitrarily.

\section{Methane sampling and measurement}

Gas sampling for methane started 0 days after rice transplanting (DAT) and ended 14 days after harvest, and the gas samples were collected once weekly from 8:00 to 10:00 a.m. The measurement of methane emissions were measured using the static closed chamber technique (Crill et al. 1988; Wang and Wang 2003). The chamber of $50-\mathrm{cm}$ length, $30-\mathrm{cm}$ breadth and 70$\mathrm{cm}$ height made of $6-\mathrm{mm}$ thick acrylic sheets were used. The height of the chambers ranging from 90 to $120 \mathrm{~cm}$ was used during the later crop-growing period to accommodate the increasing plant height. To accommodate the chamber, rectangular U-shaped aluminum channels $(50 \mathrm{~cm} \times 30 \mathrm{~cm})$ were used. The aluminum channels were inserted into the soil to a depth of $15 \mathrm{~cm}$ well ahead of gas sample collection. Each aluminum channel enclosed six plants of rice and covered an area of $0.25 \mathrm{~m}^{2}(0.5 \mathrm{~m} \times 0.5 \mathrm{~m})$ to a height of 0.5 or $1.2 \mathrm{~m}$ (according to plant height). Each chamber was equipped with interior circulating fans to ensure complete gas mixing and to minimise changes in air temperature inside the chamber during sampling. For rice-growing season, an aluminum channel was inserted in each treatment field plot and remained there during the entire monitoring period. The top edge of the frame had a groove that could be filled with water to seal the rim of the chamber. Four gas samples were collected at 15-min intervals over the course of $45 \mathrm{~min}$. Gas samples were drawn from the chambers using a $50-\mathrm{ml}$ airtight syringe fitted with a three-way stop-cock and a fine needle inserted through the other self-sealing rubber septum. The samples were brought to the laboratory immediately after collection and methane 
concentration in the gas samples were analysed using a gas chromatograph (Varian, CP-3800 GC, USA) equipped with a flame ionisation detector (FID) and a chromopack capillary column. Column, injector and detector temperatures were maintained at 50, 90 and $150{ }^{\circ} \mathrm{C}$, respectively. The gas chromatographic system was calibrated periodically with a standard obtained from National Physical Laboratory, New Delhi, India. Nitrogen (99.999\% pure) was used as a carrier gas whereas hydrogen and zero air were used for ignition of the flame in the FID. Methane fluxes $\left(\mathrm{CH}_{4} \mathrm{mg} / \mathrm{m}^{2} / \mathrm{h}\right)$ were calculated from the temporal increase in the gas concentration inside the box using the equation of Parashar et al. (1996).

\section{Statistical analysis}

The data obtained from the field-based experiment were statistically analysed using the SPSS 15.0 software package. The results were expressed as mean values of three replicates \pm standard error. Anova two ways was applied to observe a significant interaction between treatment and growth stage at $p>0.5$ level using soil and plant quality indicators during active crop growth stages (panicle initiation and flowering), following the specific soil amendment strategy. Pearson correlation analyses were performed to determine relationships among the parameters. The mean of the plant, soil and methane parameters at the harvest of various blended amendments were compared with NPK by Anova and least significant difference (LSD) tests to find out significant difference at $p>0.5$ level.

\section{Results}

Table 2 shows the result of plant height in centimetres. During the study, observation on plant height showed a visible difference amid the treatments from 14. DAT onwards while a significant difference in height was observed in T2-T5 plants in comparison to T1 plants of crop growth period, i.e. from 14 DAT to 84 DAT. Initially, the plants grown in soil treated with $\mathrm{T} 1$ were taller than the rest of the amendments, but at 56 DAT, the height of the plants growing in $\mathrm{T} 2-\mathrm{T} 5$ amendments picked up and showed noticeably a higher plant height (Table 2). At 84 DAT, the plant from T2 was the tallest $(126.00 \pm 0.57 \mathrm{~cm})$ while that of T5 was the shortest $(111.00 \pm 0.57 \mathrm{~cm})$ followed by $\mathrm{T} 4, \mathrm{~T} 3$ and $\mathrm{T} 1 \mathrm{in}$ an increasing order.

In both the stages (panicle initiation and flowering) of crop growth, the root length was longest in T2 plants $(10.83 \pm 0.60 \mathrm{~cm})$ while T3 plants $(6.26 \pm 0.92 \mathrm{~cm})$ showed the shortest. The leaf area per hill showed an increasing trend from panicle initiation stage to flowering stage for all the treatments, T5 $\left(2897 \pm 54.64 \mathrm{~cm}^{2}\right)$ showing the highest leaf area per hill in panicle initiation stage while plants of T4 $\left(6187.17 \pm 55.55 \mathrm{~cm}^{2}\right)$ in flowering stage. Soil $\mathrm{pH}$ was altered by the treatment in both the stages. During the panicle initiation, the increase in the $\mathrm{pH}$ of the soil was markedly influenced by the use of magnesium sulphate and the soil $\mathrm{pH}$ recorded 6.63. In fact, the largest increase in $\mathrm{pH}$ was observed for the $\mathrm{T} 2$, the soil with the lowest organic carbon content (Table 3 ). This was because the magnesium sulphate is a salt which solubilises easily. The sulphate group of the salt on solubilisation captured the electrons provided by decomposing materials while with other blended amendments, nutrients were in more complex forms and were slow in decomposing. Therefore, electrons were less available for neutralisation of acidity and thus failed to increase the $\mathrm{pH}$ of soil. However, in flowering period, the lowest organic matter and the highest $\mathrm{pH}$ were recorded in treatment $\mathrm{T} 1$ also having the lowest organic carbon. There is a clear transition of redox potential status from one stage to another. The redox potential during the panicle initiation stage showed an oxidised (aerobic) condition while in flowering stage exhibited a reduced (anaerobic) condition. During the panicle initiation stage, the highest accumulation of organic matter is seen in T1 $(2.76 \pm 0.41 \%)$ and the lowest in T2 $(2.34 \pm 0.19 \%)$. While in the flowering stage of crop growth, the highest accumulation of organic matter is seen in T3 $(2.70 \pm 0.19 \%)$ and the lowest in T1 $(2.22 \pm 0.26 \%)$

Table 2 LSD test-based plant height (cm) parameters (mean \pm standard error) during the crop growth period (values marked with * indicate significant difference at a significance level of 5\% in comparison with the corresponding value under T1 in the same column)

\begin{tabular}{llllll}
\hline DAT & Treatment & & & \\
\cline { 2 - 5 } & T1 & T2 & T3 & T4 & T5 \\
\hline 7 & $32.66 \pm 1.76$ & $28.83 \pm 0.44$ & $28.50 \pm 0.28$ & $33 \pm 3.78^{*}$ & $29.50 \pm 3.77$ \\
14 & $59.03 \pm 1.49$ & $37.66 \pm 0.92^{*}$ & $38.46 \pm 0.64^{*}$ & $40.26 \pm 1.02^{*}$ & $47.86 \pm 2.87^{*}$ \\
21 & $62.50 \pm 2.02$ & $53.66 \pm 0.33^{*}$ & $71.06 \pm 0.82^{*}$ & $61.53 \pm 0.90$ & $62.26 \pm 0.69$ \\
42 & $84.76 \pm 5.31$ & $81.13 \pm 3.19$ & $87.33 \pm 2.56$ & $89.80 \pm 3.98$ & $88.80 \pm 1.60$ \\
56 & $109.50 \pm 2.92$ & $114.83 \pm 9.63$ & $117.16 \pm 4.76$ & $111.16 \pm 3.76$ & $113.16 \pm 4.20$ \\
70 & $117.33 \pm 1.20$ & $121.65 \pm 1.20$ & $117.66 \pm 1.45$ & $112.33 \pm 2.51$ & $111.66 \pm 1.04$ \\
84 & $121.26 \pm 0.63$ & $126.00 \pm 0.57^{*}$ & $117.83 \pm 0.72^{*}$ & $114.00 \pm 0.57^{*}$ & $111.00 \pm 0.57^{*}$ \\
\hline DAT & & & &
\end{tabular}

DAT date after transplantation 
Table 3 Temporal variation of parameters (mean \pm standard error) of plant and soil during PI (panicle initiation) and FW (flowering) stages of the crop growth period

\begin{tabular}{|c|c|c|c|c|c|c|}
\hline \multirow[t]{2}{*}{ Stage } & \multirow[t]{2}{*}{ Parameters } & \multicolumn{5}{|l|}{ Treatments } \\
\hline & & $\mathrm{T1}$ & $\mathrm{T} 2$ & T3 & T4 & T5 \\
\hline \multirow[t]{6}{*}{ PI stage } & Root length $(\mathrm{cm})$ & $7.83 \pm 0.03$ & $10.83 \pm 0.60$ & $6.26 \pm 0.92$ & $8.53 \pm 1.46$ & $6.53 \pm 0.66$ \\
\hline & Leaf area $\left(\mathrm{cm}^{2} / \mathrm{hill}\right)$ & $806.79 \pm 150.19$ & $1185.16 \pm 94.77$ & $1299.59 \pm 151.50$ & $938.25 \pm 110.28$ & $2897 \pm 54.64$ \\
\hline & $\mathrm{pH}$ & $6.28 \pm 0.10$ & $6.63 \pm 0.14$ & $6.53 \pm 0.09$ & $6.34 \pm 0.03$ & $6.41 \pm 0.24$ \\
\hline & Redox potential (mV) & $17.33 \pm 2.33$ & $6.33 \pm 2.88$ & $5.00 \pm 1.73$ & $14.33 \pm 1.52$ & $24.66 \pm 0.57$ \\
\hline & $\begin{array}{l}\text { Electrical } \\
\text { conductance }(\mu \mathrm{s} / \mathrm{cm})\end{array}$ & $24.00 \pm 5.50$ & $28.00 \pm 1.00$ & $22.33 \pm 0.88$ & $20.33 \pm 1.85$ & $15.00 \pm 0.57$ \\
\hline & $\begin{array}{l}\text { Soil organic } \\
\text { matter (\%) }\end{array}$ & $2.76 \pm 0.41$ & $2.34 \pm 0.19$ & $2.56 \pm 0.16$ & $2.65 \pm 0.16$ & $2.65 \pm 0.11$ \\
\hline \multirow[t]{6}{*}{ FW stage } & Root length $(\mathrm{cm})$ & $10.23 \pm 0.14$ & $12.33 \pm 0.28$ & $7.86 \pm 2.05$ & $9.43 \pm 0.21$ & $8.70 \pm 0.20$ \\
\hline & Leaf area/hill (cm) & $2572.33 \pm 59.34$ & $4207.68 \pm 6.20$ & $4723.41 \pm 76.99$ & $6187.17 \pm 55.55$ & $2921.63 \pm 17.30$ \\
\hline & $\mathrm{pH}$ & $7.60 \pm 0.14$ & $7.21 \pm 0.11$ & $7.21 \pm 0.11$ & $7.31 \pm 0.16$ & $7.29 \pm 0.02$ \\
\hline & Redox potential (mV) & $-60.33 \pm 8.41$ & $-38.66 \pm 6.35$ & $-38.66 \pm 6.35$ & $-32.00 \pm 2.64$ & $-41.00 \pm 1.15$ \\
\hline & $\begin{array}{l}\text { Electrical } \\
\text { conductance }(\mu \mathrm{s} / \mathrm{cm})\end{array}$ & $36.66 \pm 4.70$ & $28.66 \pm 0.66$ & $28.66 \pm 0.66$ & $28.66 \pm 3.75$ & $31.66 \pm 1.20$ \\
\hline & Soil organic matter & $2.22 \pm 0.26$ & $2.24 \pm 0.13$ & $2.70 \pm 0.19$ & $2.47 \pm 0.08$ & $2.43 \pm 0.25$ \\
\hline \multicolumn{7}{|l|}{ Two-way ANOVA results } \\
\hline Factors & Root length $(\mathrm{cm})$ & $\begin{array}{l}\text { Leaf area } \\
\left(\mathrm{cm}^{2} / \text { hill }\right)\end{array}$ & $\mathrm{pH}$ & $\begin{array}{l}\text { Redox } \\
\text { potential }(\mathrm{mV})\end{array}$ & $\begin{array}{l}\text { Electrical conductance } \\
(\mu \mathrm{c} / \mathrm{cm})\end{array}$ & $\begin{array}{l}\text { Soil organic } \\
\text { matter (\%) }\end{array}$ \\
\hline Treatment & $p<0.000$ & $p<0.000$ & $p<0.000$ & $p<0.000$ & $p<0.104$ & $p<0.201$ \\
\hline Stage & $p<0.001$ & $p<0.000$ & $p<0.000$ & $p<0.000$ & $p<0.000$ & $p<0.000$ \\
\hline Treatment $\times$ Stage & $p<0.854$ & $p<0.000$ & $p<0.791$ & $p<0.004$ & $p<0.075$ & $p<0.599$ \\
\hline
\end{tabular}

followed by T2, T5 and T4 in an increasing order. The soil $\mathrm{pH}$ negatively and significantly correlated with the soil redox potential however positively and significantly with electrical conductance. At the same stage, the electrical conductance of soil was negatively and significantly correlated with redox potential and soil organic matter. The methane emission has positive and negative relationships with panicle length and rice yield, respectively (Table 4).

The blended amendments NPK with leaves of selected plants brought a significant difference in porosity and water-holding capacity of soil in contrast to sole inorganic fertiliser, i.e. T1 application, thus showing increase in porosity and water-holding capacity of soil for T2-T5 and improving soil physical properties. However, no significance increase in soil organic matter accumulation was seen for T2-T4 soil at harvest. Only the harvest soil of amendment T5 showed a significant increase in organic matter deposition in comparison with soil of T1. The methane emission was the lowest for T2 $(0.30 \pm 0.01 \mathrm{mg} / \mathrm{h})$ and the highest for both T3 and T4 $(0.34 \pm 0.01 \mathrm{mg} / \mathrm{h})$ while $\mathrm{T} 5$ showed a similar trend of methane emission with $\mathrm{T} 1$. The yield of the rice plant of T2, T3 and T5 increased in comparison with $\mathrm{T} 1$. The rice plants grown in $\mathrm{T} 4$ showed the lowest yield $\left(0.505 \pm 0.05 \mathrm{~kg} / \mathrm{m}^{2}\right)$.

Table 4 Correlation coefficient with some of the parameters of soil and plant during the crop growth period where values marked with* indicate significant difference at a significance level of $5 \%$ and with** indicate that at a significance level of 1\%

\begin{tabular}{lll}
\hline Parameter & Parameter & Pearson correlation coefficient \\
\hline $\mathrm{pH}$ & Redox potential & $-0.945^{* *}$ \\
$\mathrm{pH}$ & Electrical conductance & $0.631^{* *}$ \\
Redox potential & Electrical conductance & $-0.707^{* *}$ \\
Soil organic matter & Electrical conductance & $-0.381^{*}$ \\
Root length & Soil organic matter & $-0.437^{*}$ \\
Root length & Redox potential & $-0.499^{* *}$ \\
Soil porosity & Water-holding capacity & $0.545^{*}$ \\
Methane emission & Water-holding capacity & 0.456 \\
\hline
\end{tabular}




\section{Discussion}

The plant height in all five amendments was measured at 14-day intervals. The plants growing on soil treated with inorganic fertiliser NPK (T1) easily absorbed the soluble nutrients which paved way for a faster growth of plants at an early stage. However, after 42 DAT with augmented SOM, the growth pace of plants of T3-T5 was similar with plants in NPK amendments (T1). At 56 DAT, the height of the plants growing in soil amendments T2-T5 picked up and showed a comparably higher plant height at maturation stage than $\mathrm{T} 1$ plants.

Monitoring the changes in soil and plant quality indicators during active growth stage of crop, following a specific management strategy is a useful approach to determine soil and plant quality status. In this regard, the plant traits like the root length and the leaf area/hill showed a significant statistical difference among the amendments and between two active growth stages (panicle initiation and flowering), while no such differences among amendments and the two active growth stages occurred with respect to soil attributes like soil $\mathrm{pH}$, soil organic matter and soil electric conductance. However, a significant change in soil redox potential in response to the experimental amendments and the two active growth stages (Table 3) was found, suggesting that changes in soil redox potential were easily detected in the short-term management practices. Two important parameters in soil science are redox potential and $\mathrm{pH}$ which together influence nutrient availability and bring salient changes in soil organic matter content and other associated factors affecting plant growth and productivity in a rainfed soil (Ponnamperuma 1972; Sahrawat 1998; Sahrawat 2007; Husson 2013; Sahrawat 2015). In the present study, during flowering stage, soil condition reduced which reinforced slower decomposition of organic matter (Chesworth 2004). The soil pH near neutrality along with a reduced Eh lead to a higher fertiliser efficiency because plants release less share of their photosynthetic production as root exudate in order to adjust the redox potential of the soil ensuring homeostasis (Husson 2013). This was a clear indication of better yield at harvest as plants accumulated higher biomasses thus lowering methane emission.

Methane is an end product of organic matter decomposition under anaerobic soil conditions. Therefore, the two strategies often proposed to reduce methane emissions are to limit the period of soil submergence (Jain et al. 2014) and reduce carbon inputs through usage of alternative electron acceptors, selecting low emission rice varieties (Bharali et al. 2016), composting of organic materials (Chen et al. 2014) supplied to rice field. Such management practices require specialised skills and efficient resource handling. However, the existing study focuses on the application of magnesium sulphate and leaves of commonly available plant materials in the form of blend with NPK in rainfed rice soil to curb methane emission, while fulfilling the nutritional requirement of high-yielding rice variety in return enhancing yield and soil fertility in a cost-effective way. The existent study also indicates that the application of leaves of plant material-based amendments has positive effects on soil properties like soil porosity and waterholding capacity (Table 5). The amendment T5 significantly increased SOM accumulation in soil. This is consistent with the view that plant materials can be an important input for increasing soil quality in rice production systems (Lee et al. 2010). Thus, the application of blended amendments with leaves as plant materials to rainfed condition fields is the key in promoting physical attributes of soil quality in agricultural systems without intensifying methane emission in comparison to sole application of inorganic fertiliser NPK, though the treatments enhanced the yield but were not effective in bringing statically difference in yield among the treatments.

Table 5 One way-ANOVA and LSD test-based soil properties at the harvest of the crop in the year 2015 (values marked with* indicate significant difference at a significant level of 5\% in comparison to the corresponding value under T1 in the same column)

\begin{tabular}{lllllll}
\hline Treatment & $\begin{array}{l}\text { Soil } \\
\text { porosity (\%) }\end{array}$ & $\begin{array}{l}\text { Water-holding } \\
\text { capacity (\%) }\end{array}$ & $\begin{array}{l}\text { Soil organic } \\
\text { matter }(\%)\end{array}$ & $\begin{array}{l}\text { Panicle } \\
\text { length }(\mathrm{cm})\end{array}$ & $\begin{array}{l}\text { Grain yield } \\
\left(\mathrm{kg} / \mathrm{m}^{2}\right)\end{array}$ & $\begin{array}{l}\text { Methane emission } \\
\left(\mathrm{mg} / \mathrm{m}^{2} / \mathrm{h}\right)\end{array}$ \\
\hline T1 & $38.50 \pm 1.27$ & $19.66 \pm 4.93$ & $1.95 \pm 0.03$ & $27.93 \pm 0.29$ & $0.533 \pm 0.02$ & $0.33 \pm 0.00$ \\
T2 & $46.30 \pm 0.88^{*}$ & $25 \pm 5.03$ & $2.10 \pm 0.12$ & $24.46 \pm 0.68^{*}$ & $0.531 \pm 0.02$ & $0.30 \pm 0.01^{*}$ \\
T3 & $50.20 \pm 1.27^{*}$ & $34 \pm 1.52^{*}$ & $2.09 \pm 0.01$ & $28.26 \pm 0.34$ & $0.540 \pm 0.02$ & $0.34 \pm 0.01^{*}$ \\
T4 & $43.90 \pm 1.27^{*}$ & $31 \pm 4.16^{*}$ & $2.15 \pm 0.01$ & $26.16 \pm 0.35^{*}$ & $0.505 \pm 0.05$ & $0.34 \pm 0.01^{*}$ \\
T5 & $43.80 \pm 0.90^{*}$ & $35 \pm 3.05^{*}$ & $2.48 \pm 0.10^{*}$ & $27.40 \pm 0.25$ & $0.560 \pm 0.01$ & $0.33 \pm 0.01$ \\
ANOVA significance & 0.004 & 0.002 & 0.106 & 0.000 & 0.787 & 0.001 \\
LSD significance & & & & & 0.970 & 0.014 \\
T1 $\times$ T2 & 0.005 & 0.111 & 0.393 & 0.000 & 0.873 & 0.061 \\
T1 $\times$ T3 & 0.000 & 0.001 & 0.424 & 0.585 & 0.014 & 0.523 \\
T1 $\times$ T4 & 0.033 & 0.007 & 0.257 & 0.388 & 0.014 \\
T1 $\times$ T5 & 0.033 & 0.001 & 0.012 & & & 0.418 \\
\hline
\end{tabular}




\section{Conclusions}

From the current field experiment, it is observed that magnesium sulphate blended with NPK can serve as an alternative to sole NPK amendment to decrease methane emission significantly in the flooded rice paddy soil at $0.5 \mathrm{t} / \mathrm{ha}$ application level. The present study demonstrates that the application of leaves of neemmixed NPK, tea leaves mixed with NPK and karanjmixed NPK in rainfed rice fields is the key in promoting physical attributes of soil quality as well as yield in agricultural systems in comparison with the exclusive application of inorganic fertiliser NPK. It is suggested that the rice productivity can be improved with significant increase in soil organic matter without intensifying methane emission when fresh leaves of karanj at $1 \mathrm{t}$ /ha blended with NPK are applied on the rainfed rice fields in an acidic soil before transplantation. Long-term studies might be needed to ensure blending of fresh karanj with inorganic fertiliser NPK to be established as an alternative to inorganic fertilisation which can sustainably improve rice productivity in paddy rice fields, consequently reducing the emission of methane and minimising its global warming potential in the environment.

\section{Acknowledgements}

I acknowledge Tezpur University in providing the experimental field area and other necessary help in conducting and completing the research work.

\section{Funding}

There is no funding body in the design of the study and collection, analysis, and interpretation of data and in writing the manuscript other than the minimum laboratory facilities provided by the parent institute. The problem was undertaken as one of the objectives of Ph.D. work of the first author.

\section{Authors' contributions}

MG collected the data and performed the data analysis. She also drafted and wrote the manuscript. AD was part of the research design and manuscript editing. Both authors read and approved the final manuscript.

\section{Competing interests}

The authors declare that they have no competing interests.

\section{Publisher's Note}

Springer Nature remains neutral with regard to jurisdictional claims in published maps and institutional affiliations.

Received: 2 June 2017 Accepted: 23 September 2017

Published online: 13 October 2017

\section{References}

Alexandratos N, Bruinsma J (2012) World agriculture towards 2030/2050: the 2012 revision. ESA working paper, Rome, FAO

Audebert A, Sahrawat KL (2000) Mechanisms for iron toxicity tolerance in lowland rice. J Plant Nutr 23:1877-1885

Aulakh MS, Wassmann R, Bueno C, Kreuzwieser J, Rennenberg H (2001) Characterization of root exudates at different growth stages of ten rice (Oryza sativa L.) cultivars. Plant Biology 3:139-148

Becker M, Asch F (2005) Iron toxicity in rice-conditions and management concepts. J Plant Nutr Soil Sci 168:558-573

Bharali A, Baruah KK, Gogoi N (2016) Methane emission from irrigated rice ecosystem: relationship with carbon fixation, partitioning and soil carbon storage. Paddy Water Environment. https://doi.org/10.1007/s10333-016-0541-3
Bodelier PL (2015) Sustainability: bypassing the methane cycle. Nature 523:534-535

Chen X, Cui Z, Fan M et al (2014) Producing more grain with lower environmental costs. Nature 514:486-489

Chesworth W (2004) Redox, soil and carbon sequestration. Edafologia 11:37-43

Crill PM, Bartlett KB, Harriss RC, Gorham E, Verry ES, Sebacher DI, Madzer L, Sanner W (1988) Methane flux from Minnesota peatlands. Glob Biogeochem Cycles 2:371-384

Datta A, Adhya TK (2014) Effects of organic nitrification inhibitors on methane and nitrous oxide emission from tropical rice paddy. Atmos Environ 92:533-545

FAOSTAT (2006) Food and Agriculture Organization of the United Nations. FAOSTAT. http://faostat.fao.org/default.aspx (Accessed 1 May 2017)

FAO (2011) Food and Agriculture Organization of the United Nations, Rome. Data available at http://www.fao.org

Hussain S, Peng S, Fahad S, Khaliq A, Huang J, Cui K, Nie L (2015) Rice management interventions to mitigate greenhouse gas emissions: a review. Environ Sci Pollut Res 22:3342-3360

Husson O (2013) Redox potential (Eh) and pH as drivers of soil/plant/ microorganism systems: a transdisciplinary overview pointing to integrative opportunities for agronomy. Plant Soil 362:389-417

IPCC (2013) Contribution of working group I to the fifth assessment report of the intergovernmental panel on climate change, Climate Change 2013: The Physical Science Basis. Cambridge University Press, Cambridge

Jain N, Dubey R, Dubey DS, Singh J, Khanna M, Pathak H, Bhatia A (2014) Mitigation of greenhouse gas emission with system of rice intensification in the Indo-Gangetic Plains. Paddy Water Environment 12:355-363

Kato Y, Collard BCY, Septiningsih EM, Ismail AM (2014) Physiological analyses of traits associated with tolerance of long-term partial submergence in rice. AoB PLANTS 6, plu058, https://doi.org/10.1093/ aobpla/plu058

Lee CH, Park KD, Jung KY, Ali MA, Lee D, Gutierrez J, Kim PJ (2010) Effect of Chinese milk vetch (Astragalus sinicus L.) as a green manure on rice productivity and methane emission in paddy soil. Agriculture, Ecosystem and Environment 138:343-347

Linquist B, Sengxua P (2001) Nutrient Management of Rainfed Lowland Rice in the Lao PDR. International Rice Research Institute, Los Banos, p 88

Linquist BA, Anders MM, Adviento Borbe MAA, Chaney RL, Nalley LL, da Rosa EFF, van Kessel C (2015) Reducing greenhouse gas emissions, water use, and grain arsenic levels in rice systems. Glob Chang Biol 21:407-417

Linquist J, van Groenigen BA, Adviento-Borbe KJ, Pittelkow MA, van Kessel CM (2012) An agronomic assessment of greenhouse gas emissions from major cereal crops. Glob Chang Biol 18:194-209

Mackill DJ, Ismail AM, Singh US, Labios RV, Paris TR (2012) Development and rapid adoption of submergence-tolerant (Sub1) rice varieties. Advances in Agronomy 115:299-252

Parashar DC, Mitra AP, Gupta PK, Rai J, Sharma RC, Singh N, Koul S, Ray HS, Das SN, Parida KM, Rao SB, Kanungo SP, Ramasami T, Nair BU, Swamy M, Singh G, Gupta SK, Singh AR, Saikia BK, Baruah AKS, Pathak MG, lyer CSP, Gopalakrishnan M, Sane PV, Singh SN, Banerjee R, Sethunathan N, Adhya TK, Rao VR, Palit P, Saha AK, Purkait N, Chaturvedi GS, Sen SP, Sen M, Sarkar B, Banik A, Subbaraya BH, Lal S, Venkatramani S, Lal G, Chaudhary A, Sinha SK (1996) Methane budget from paddy fields in India. Chemosphere 33:737-757

Pittelkow CM, Liang X, Linquist BA, van Groenigen KJ, Lee J, Lundy ME, van Gestel N, Six J, Venterea RT, van Kessel C (2015) Productivity limits and potentials of the principles of conservation agriculture. Nature 517:365-368 Ponnamperuma FN (1972) The chemistry of submerged soils. Adv Agron 24:29-96

Ruehlmann J, Korschens M (2009) Calculating the effect of soil organic matter concentration on soil bulk density. Soil Sci Soc Am J 73:876-885

Sahrawat KL (1998) Flooding soil: a great equalizer of diversity in soil chemical fertility. Oryza 35:300-305

Sahrawat KL (2007) Soil fertility advantages of submerged rice cropping systems: a review. J Sustain Agric 31:5-23

Sahrawat KL (2015) Redox potential and pH as major drivers of fertility in submerged rice soils: a conceptual framework for management. Commun Soil Sci Plant Anal 46:1597-1606

Sarangi SK, Maji B, Singh S, Sharma DK, Burman B, Mandal SUS, Ismail AM, Haefele SM (2016) Using improved variety and management enhances rice productivity in stagnant flood affected tropical coastal zones. Field Crop Res 190:70-81

Van Der Gon HACD, Kropff MJ, van Breemen N et al (2002) Optimizing grain yields reduces $\mathrm{CH}_{4}$ emission from rice paddy fields. Proc Natl Acad Sci 99: 12021-12024 
Vergara GV, Nugraha Y, Esguerra MQ, Mackill DJ, Ismail AM (2014) Variation in tolerance of rice to long-term stagnant flooding that submerges most of the shoot will aid in breeding tolerant cultivars. AoB PLANTS 6 https://doi.org/10 1093/aobpla/plu055

Wang $\mathrm{Y}$, Wang $\mathrm{Y}$ (2003) Quick measurement of $\mathrm{CH}_{4}, \mathrm{CO}_{2}$ and $\mathrm{N}_{2} \mathrm{O}$ emissions from a short-plant ecosystem. Adv Atmos Sci 20:842-844

Zhao X, Liu SL, Pu C, Zhang XQ, Xue JF, Zhang R, Wang YQ, Lal R, Zhang HL, Chen $F(2016)$ Methane and nitrous oxide emissions under no-till farming in China: a meta-analysis. Glob Chang Biol 22:1372-1384

Submit your manuscript to a SpringerOpen ${ }^{\circ}$ journal and benefit from:

- Convenient online submission

- Rigorous peer review

- Open access: articles freely available online

- High visibility within the field

- Retaining the copyright to your article

Submit your next manuscript at $\boldsymbol{\sim}$ springeropen.com 